\title{
PEMBUATAN FLAKES DENGAN VARIASI TEPUNG GANDUM DAN TEPUNG KELAPA DALAM UPAYA PENINGKATAN MUTU FLAKES
}

\author{
Flakes Making With Variations of Wheat Flour And Coconut Flour in Efforts to Improve \\ Flakes Quality
}

\author{
Aprilia Nurhidayanti ${ }^{1)}$, Sari Astina Dewi ${ }^{1)}$ dan Narsih ${ }^{2)}$ \\ ${ }^{1}$ Mahasiswa Jurusan Teknologi Pertanian Prodi Teknologi Pengolahan Hasil Perkebunan \\ ${ }^{2}$ Dosen Jurusan Teknologi Pertanian Prodi Teknologi Pengolahan Hasil Perkebunan \\ e-mail : narsih78@gmail.com
}

\begin{abstract}
Flakes coconut is a food fiber made from wheat flour with variations of coconut flour (30\%, $40 \%$, and 50\%). Methods of making coconut flakes are, mixing, forming, sheeting, printing and baking. The best coconut flakes with $70 \%$ wheat flour formulations and $30 \%$ coconut flour, $2.273 \%$ moisture content, $0.79 \%$ ash content, $16.36 \%$ fat content, $76.672 \%$ carbohydrate content, 0.299 fiber content and 3.905 protein content. Based on the scoring test and hedonic flakes test the coconut panelists are accepted with 70\%, 30\% formulation with coconut flakes flavored with coconut taste, cream color, crispy texture and coconut color. The average of coconut flakes produced has fulfilled SNI cereals no. 01-4270-1996 on the parameters of water content, ash content, fat content, carbohydrate levels, coarse fiber content and protein content
\end{abstract}

Keywords: coconut, coconut flour, flakes

\begin{abstract}
ABSTRAK
Flakes kelapa merupakan makanan serat berbahan baku tepung gandum dengan variasi penambahan tepung kelapa $(30 \%, 40 \%$, dan 50\%). Metode pembuatan flakes kelapa yaitu, pencampuran, pembentukan, lembaran, pencetakan dan pemanggangan. Flakes kelapa yang terbaik dengan formulasi tepung gandum 70\% dan tepung kelapa 30\%, kadar air 2,273\%, kadar abu 0,79\%, kadar lemak 16,36\%, kadar karbohidrat 76,672\%, kkadar serat 0,299 dan kadar protein 3,905. Berdasarkan uji scoring dan uji hedonik flakes kelapa panelis diterima dengan formulasi 70\%;30\% dengan rasa flakes kelapa berasa kelapa, berwarna cream, tekstur renyah dan berwarna kelapa. Rerata flakes kelapa yang dihasilkan telah memenuhi SNI sereal No. 014270-1996 pada parameter kadar air, kadar abu, kadar lemak, kadar karbohidrat, kadar serat kasar dan kadar protein
\end{abstract}

Kata kunci : kelapa, tepung kelapa, flakes

\section{PENDAHULUAN}

Sebagai hasil perkebunan yang terbesar di Kalimantan Barat, kelapa dapat dimanfaatkan menjadi produk siap saji yaitu dalam bentuk flakes yang dikompositkan dengan tepung gandum sehingga menjadi produk sereal sarapan siap santap yang cukup digemari oleh masyarakat yang semakin menginginkan kepraktisan serta kemudahan. Hal ini disebabkan terutama karena keterbatasan waktu pada pagi hari untuk menyiapkan makanan sarapan.

Flakes merupakan makanan berbentuk lembaran tipis berwarna kuning kecoklatan serta biasa dikonsumsi dengan penambahan susu sebagai menu sarapan. Produk ini dapat diolah dengan teknologi sederhana, waktu yang singkat dan cepat dalam penyajian, untuk mencoba menjawab permasalahan di 
atas, maka dibutuhkan suatu bentuk makanan yang mudah serta dapat cepat disajikan untuk sarapan pagi. Diharapkan sereal sarapan dari kelapa dapat dijadikan salah satu bentuk makanan yang dapat langsung dikonsumsi atau hanya memerlukan sedikit waktu dalam persiapannya. Flakes yang saat ini beredar di pasaran terbuat dari serealia yaitu, gandum yang terkenal dengan wheat atau oatflakes dan jagung yang dikenal dengan corn flakes. Flakes yang biasanya dibuat dengan bahan dasar gandum yang terlalu banyak dapat menyebabkan adonan flakes rapuh sehingga sulit untuk dilakukan proses pencetakan, sebagai penganti gandum digunakan tepung gandum pada pembuatan flakes, namun jika terlalu banyak penggunaan tepung gandum dapat membuat adonan lengket dan menghasilkan flakes yang keras, maka dilakukan penambahan tepung kelapa pada flakes, agar komponen yang bermanfaat pada kelapa dapat dijadikan sebagai nilai tambah pada produk flakes. Selain karena buah kelapa banyak mengandung lemak dan serat pangan yang baik, juga sebagai sumber kalium yang tinggi. Penambahan tepung kelapa dalam pembuatan flakes makanan selain karena kandungan gizinya cukup lengkap, memberikan aroma yang khas, juga sebagai salah satu alternatif agar memudahkan dalam proses pencetakan flakes dari usaha penganekaragaman hasil kelolaan dan untuk meningkatkan nilai ekonomisnya.

Tepung kelapa diperoleh dari daging buah kelapa tua yang diolah melalui proses pembuangan sabut dan tempurung kelapa, pemisahan testa, pencucian, pemarutan, pengeringan dan penepungan. Keunggulan dari pengolahan kelapa menjadi tepung adalah meningkatkan daya guna, hasil guna dan nilai guna. Lebih mudah dicampur dengan tepung-tepung dan bahan lainnya, namun belum diketahui proporsi perbandingan penambahan tepung gandum dan tepung kelapa dalam pembuatan flakes.

\section{BAHAN DAN METODE}

\section{Bahan dan alat}

Bahan - bahan yang digunakan dalam penelitian ini yaitu tepung kelapa tepung gandum, tepung maizena, gula halus, air galon, telur margarine diperoleh dari toko Centrum. Bahan kimia yang digunakan yaitu aquades, $\mathrm{CuSO} 4, \mathrm{NaOH}, \mathrm{H} 2 \mathrm{C} 2 \mathrm{O} 4.2 \mathrm{H} 2 \mathrm{O} 3$, n-hexana, H2SO4, HCL, larutan indikator bromkesol hijau $0,1 \%$, larutan indikator metil merah $0,1 \%$ diperoleh dari laboratorium terkait tempat produk di analisa.

Peralatan yang digunakan pada pembuatan flakes yaitu pisau, loyang, pengaduk, baskom, keranjang, pengupas kentang, talenan, sarung tangan, serbet dan ayakan diperoleh dari toko terdekat.

Alat kimia yang digunakan untuk menganalisa flakes yaitu tissu, masker, sarung tangan, gelas ukur, desikator, neraca analitik, krus porselin, erlenmeyer, kabinet dryer, oven dan tanur.

\section{Tahapan penelitian}

\section{Pembutaan tepung kelapa}

Kelapa dikupas, dipisahkan testanya, dibersihkan atau dicuci, kemudian diparut dan di lakukan pengepresan lalu dikeringkan setelah itu didinginkan dan diayak dengan mesh 80 untuk menyeragamkan tepung kelapa.

\section{Pembuatan Flakes kelapa}

Semua bahan dicampur sesuai dengan formulasi yang telah ditentukan (Tabel 1). tepung gandum, tepung kelapa, gula halus, margarine dan tepung maizena dicampur hingga tercampur sempurna, Kemudian dilakukan penambahan air+telur sedikit demi sedikit untuk pembuatan adonan, lalu adonan dicetak dan disusun diloyang dan dilanjutkandengan tahap pengovenan hingga berwarna kuning kecoklatan. Formulasi bahan baku pembuatan flakes kelapa dapat dilihat pada Tabel 1. 
Tabel 1. Formulasi flakes untuk setiap $100 \mathrm{~g}$ tepung komposit

\begin{tabular}{lccccccccccc}
\hline \multirow{2}{*}{\begin{tabular}{l} 
Komposisi \\
\multicolumn{1}{c}{ Bahan }
\end{tabular}} & TG & TK & $\begin{array}{c}\text { TG } \\
11\end{array}$ & $\begin{array}{c}\text { TG } \\
12\end{array}$ & $\begin{array}{c}\text { TG } \\
13\end{array}$ & $\begin{array}{c}\text { TG } \\
21\end{array}$ & $\begin{array}{c}\text { TG } \\
22\end{array}$ & TG & TG & TG & TG \\
\hline $\begin{array}{l}\text { Tepung } \\
\text { gandum } \\
\text { (g) }\end{array}$ & 100 & 0 & 70 & 70 & 70 & 60 & 60 & 60 & 50 & 50 & 50 \\
$\begin{array}{l}\text { Tepung } \\
\text { kelapa (g) }\end{array}$ & 0 & 100 & 30 & 40 & 50 & 30 & 40 & 50 & 30 & 40 & 50 \\
$\begin{array}{l}\text { Mentega } \\
\text { (g) }\end{array}$ & 20 & 20 & 20 & 20 & 20 & 20 & 20 & 20 & 20 & 20 & 20 \\
$\begin{array}{l}\text { Gula halus } \\
\text { (g) }\end{array}$ & 20 & 20 & 20 & 20 & 20 & 20 & 20 & 20 & 20 & 20 & 20 \\
$\begin{array}{l}\text { Tepung } \\
\text { maizena } \\
\text { (g) }\end{array}$ & 20 & 20 & 20 & 20 & 20 & 20 & 20 & 20 & 20 & 20 & 20 \\
\hline
\end{tabular}

\section{Rancangan penelitian}

Penelitian ini dilakukan di Laboratorium Universitas Muhammadiyah Malang pada bulan Mei 2017. Rancangan percobaan yang dipakai dalam penelitin ini adalah Rancangan Acak Lengkap (RAL) dengan perbandingan tepung gandum dan tepung kelapa yang terdiri dari 11 perlakuan, yaitu TG (100:0), TK (100:0) TG11 (70:30), TG12 (70:40), TG13 (70:50), TG21 (60:30), TG22 (60:40), TG23 (60:50), TG31 (50:30), TG32 (50:40), TG33 (50:50).

\section{Parameter yang diamati}

Parameter yang diamatai adalah analisa kadar air (metode thermogravimetri), analisa kadar abu (metode thermogravimetri), analisa kadar lemak (metode soxhlet), analisa kadar karbohidrat, analisa kadar serat kasar, analisa kadar protein dan uji sensoris dengan metode skoring (warna, tekstur, rasa, aroma) dan tingkat kesukaan/Hedonik).

\section{HASIL DAN PEMBAHASAN}

\section{Kadar air}

Penentuan kadar air dalam bahan makanan penting dilakukan untuk mengetahui umur simpan bahan tersebut.
Kadar air merupakan banyaknya air yang terkandung dalam bahan yang dinyatakan dalam persen. Kadar air juga salah satu karakteristik yang penting pada bahan pangan, karena air dapat mempengaruhi penampakan, tekstur dan citarasa pada bahan pangan (Winarno, 2002).

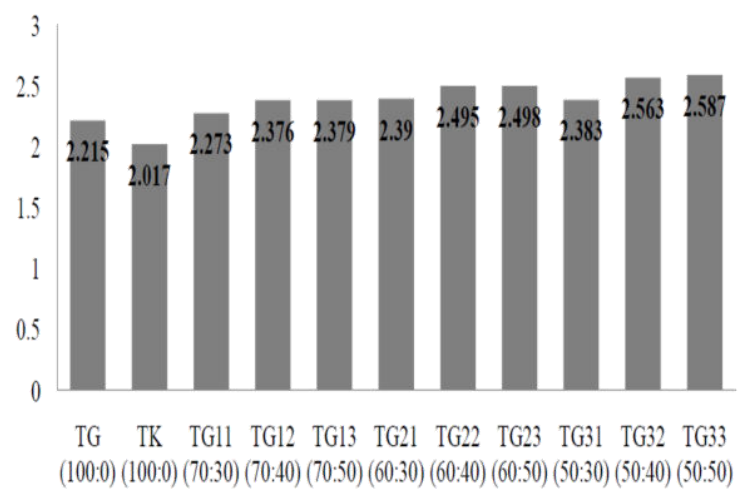

Gambar 1. Diagram batang kadar air flakes

Berdasarkan hasil analisa kadar air terhadap 11 formulasi, pada Gambar 1 menunjukkan bahwa adanya pengaruh formulasi tepung kelapa terhadap kadar air yang dihasilkan. Hal ini dipengaruhi oleh tingginya kadar serat tepung kelapa, sehingga semakin banyak tepung ampas kelapa yang digunakan, semakin tinggi kadar air yang dapat diikat. Serat dapat mengikat air lima kali lipatnya dan me- 
ningkatnya kadar air juga diakibatkan oleh tingginya kadar air pada tepung gandum hampir mendekati $10 \%$. Secara keseluruhan flakes kelapa memenuhi SNI sereal No.014270-1996 yaitu maksimal 3\%.

\section{Kadar abu}

Kadar abu dari suatu bahan pangan menunjukkan residu bahan anorganik yang tersisa setelah suatu bahan dibakar sampai bebas karbo (Monika dkk, 2014). Kadar abu adalah residu anorganik dari proses pengabuan yang mengindikasikan kandungan mineral dalam bahan makanan.

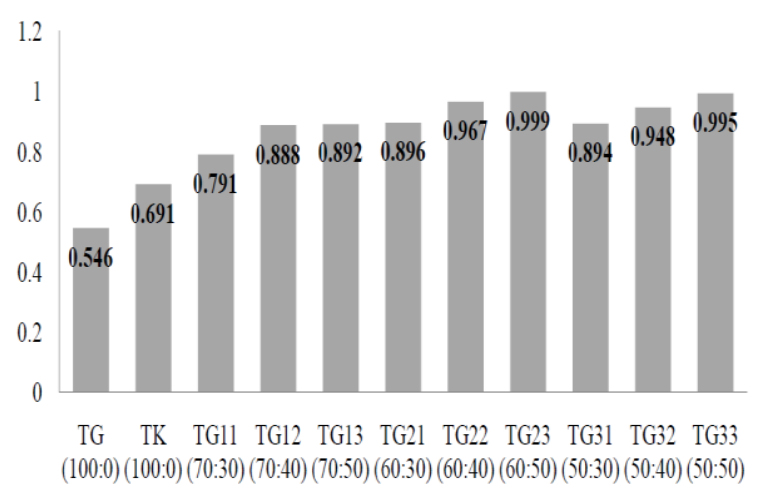

Gambar 2. Diagram batang kadar abu flakes

Berdasarkan hasil analisa kadar abu terhadap 9 formulasi, pada Gambar 2 menunjukkan bahwa adanya pengaruh formulasi tepung kelapa terhadap kadar abu yang dihasilkan. Hal ini dipengaruhi oleh kadar mineral pada tepung kelapa, karena tepung kelapa mengandung kadar mineral dan pengotor yang cukup tinggi. Secara keseluruhan flakes kelapa kadar abunya memenuhi SNI sereal No. 01-4270-1996 yaitu maksimal $4 \%$.

\section{Kadar lemak}

Lemak berperan dalam menambah kalori serta memperbaiki tekstur dan cita rasa bahan pangan. Lemak merupakan sumber energi bagi tubuh yang lebih efektif dan satu gram lemak mampu menghasilkan 9 kkal energi.

Berdasarkan hasil analisa kadar lemak terhadap 9 formulasi, pada Gambar 3 menunjukkan bahwa adanya pengaruh formulasi tepung kelapa terhadap kadar lemak yang dhasilkan. Hal ini dipengaruhi oleh kandungan lemak yang cukup tinggi pada tepung kelapa, semakin tinggi penambahan tepung ampas kelapa, maka semakin tinggi pula kadar lemak yang terkandung dalam flakes. Selain itu, tingginya kadar lemak juga dipengaruhi oleh penambahan margarine dan telur dalam pembuatan flakes, maka kadar lemak yang dihasilkan semakin tinggi. Secara ke-seluruhan flakes kelapa kadar lemaknya memenuhi SNI sereal No. 01- 4270-1996 yaitu minimal 7\%.

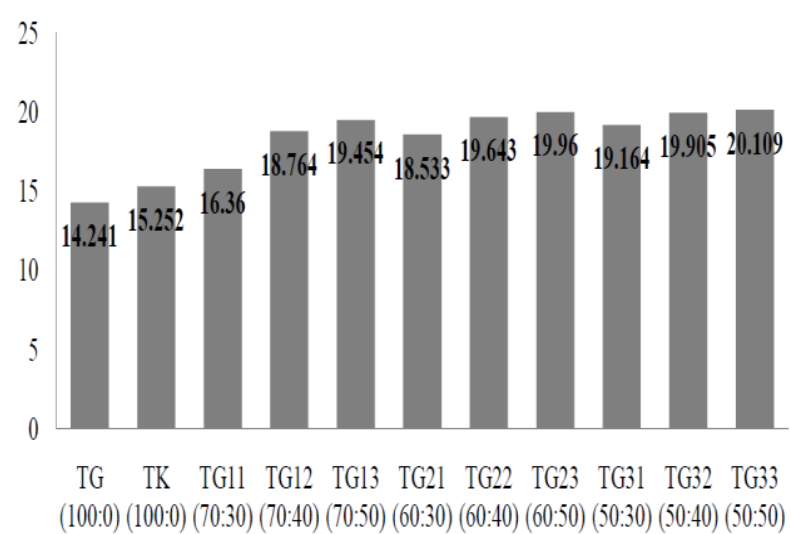

Gambar 3. Diagram batang kadar lemak flakes

\section{Kadar karbohidrat}

Berdasarkan hasil analisa kadar karbohidrat terhadap 9 formulasi, pada Gambar 4 menunjukkan bahwa adanya pengaruh formulasi tepung kelapa terhadap kadar karbohidrat yang dihasilkan. Hal ini dipengaruhi oleh rendahnya kadar karbohidrat tepung kelapa dan penambahan tepung gandum juga berpengaruh terhadap turunnya kadar karbohidrat pada flakes. Semakin tinggi penggunaan tepung kelapa, maka kadar karbohidrat flakes semakin rendah. Menurut Saputra (2015), kadar karbohidrat dipengaruhi oleh komponen nutrisi lain, semakin rendah komponen nutrisi lain, maka kandungan karbohidrat semakin tinggi, begitu sebaliknya semakin tinggi komponen nutrisi lain maka kandungan karbohidrat semakin rendah. Secara keseluruhan flakes kelapa kadar karbohidratnya memenuhi SNI sereal No. 014270-1996 yaitu minimal 60\%. 


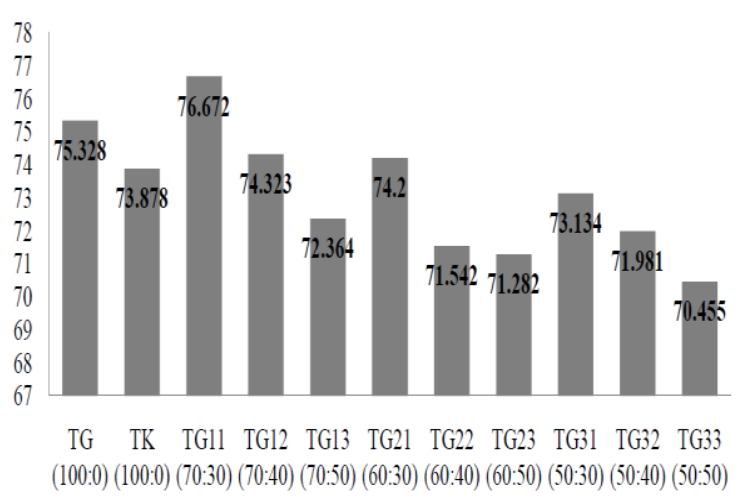

Gambar 4. $\begin{gathered}\text { Diagram batang kadar } \\ \text { karbohidrat flakes }\end{gathered}$

\section{Kadar serat kasar}

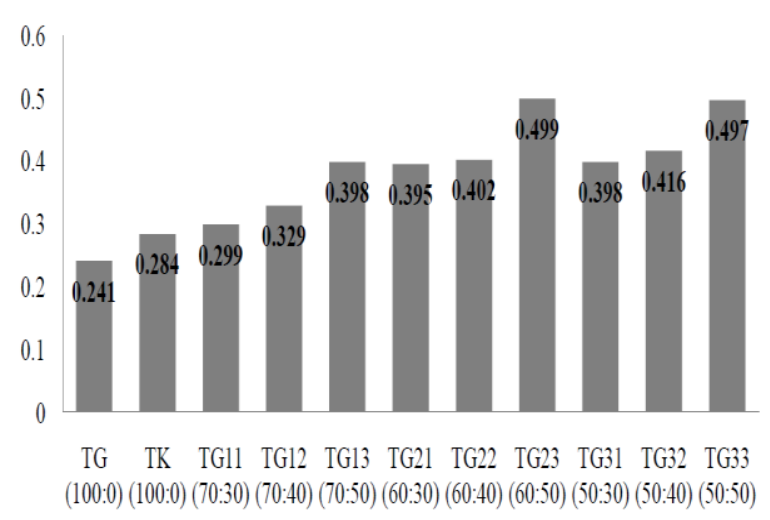

Gambar 5. Diagram batang kadar serat kasar flakes

Berdasarkan hasil analisa kadar serat kasar terhadap 9 formulasi, pada Gambar 5 menunjukkan bahwa adanya pengaruh formulasi tepung kelapa terhadap kadar serat kasar yang dihasilkan. Semakin banyak tepung kelapa yang ditambahkan, maka kadar serat kasar pada flakes semakin tinggi. Hal ini dikarenakan kadar serat tepung kelapa $(5,434 \%)$ lebih tinggi dibandingkan tepung terigu $(3,186 \%)$, selain itu juga disebabkan karena tepung kelapa merupakan sumber serat pada flakes, sehingga bisa bermanfaat sebagai makanan kesehatan. Serat pangan dari flakes juga dapat mengontrol pelepasan glukosa seiring waktu, membantu pengontrolan dan pengaturan diabetes melitus dan obesitas (Trinidad, 2002). Serat pangan dalam jumlah yang cukup di dalam makanan sangat bagus untuk pencernaan yang baik dalam usus.Secara keseluruhan flakes kelapa kadar serat kasarnya memenuhi SNI sereal No. 014270-1996 yaitu maksimal 7\%.

\section{Kadar protein}

Protein merupakan zat makanan yang penting bagi tubuh karena memiliki fungsi antara lain sebagai zat pembangun dan sumber energi. Protein merupakan makromolekul yang tersusun oleh asamasam amino yang mengandung unsur $\mathrm{C}, \mathrm{O}$, $\mathrm{H}$ dan $\mathrm{N}$, selain itu juga mengandung $\mathrm{S}, \mathrm{P}$ dan $\mathrm{Fe}$ pengukuran protein dengan penentuan protein kasar yang bertujuan untuk menera jumlah protein total yang terdapat dalam bahan pangan (Budianto, 2009).

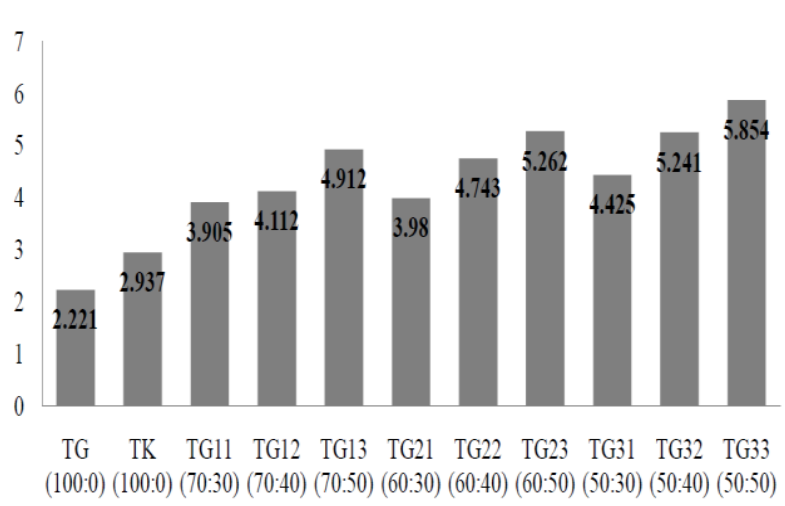

Gambar 6. Diagram batang kadar protein flakes

Berdasarkan hasil analisa kadar protein terhadap 9 formulasi dapat dilihat pada Gambar 6 menunjukkan bahwa adanya pengaruh formulasi tepung kelapa terhadap kadar protein yang dihasilkan. Hal ini disebabkan karena kadar protein tepung kelapa lebih tinggi dibanding tepung gandum. Semakin tinggi tepung kelapa yang digunakan, maka semakin meningkat pula kadar protein pada flakes. Secara keseluruhan flakes kelapa kadar proteinnya memenuhi SNI sereal No. 01-4270-1996 yaitu minimal $5 \%$.

\section{Uji organoleptik}

Uji organoleptik merupakan faktor terpenting untuk mengetahui penerimaan panelis terhadap suatu produk. Pada umumnya pertimbangan seseorang dalam meng- 
konsumsi makanan dengan mutu organoleptiknya seperti tekstur, aroma, warna dan rasa produk, bahkan terhadap tingkat kesukaan konsumen pada produk.

\section{Tekstur}

Hasil pengujian tekstur flakes kelapa, memperlihatkan terhadap perbedaan yang nyata dari 11 produk yang di uji. Berdasarkan pengujian uji skoring dan uji hedonik tekstur flakes kelapa panelis menunjukkan bahwa F-hitung sampel yaitu $(0,0882)$ lebih rendah dari F-tabel pada taraf $5 \%$ yaitu $(4,65)$ dan pada taraf $1 \%$ yaitu $(9,89)$, hal ini menunjukkan sampel tidak berbeda nyata. Hal ini menunjukkan sampel tidak berbeda nyata.

Hasil uji hedonik menunjukkan Fhitung sampel yaitu $(0,0223)$ lebih rendah dari F-tabel pada taraf $5 \%$ yaitu $(4,65)$ dan pada taraf $1 \%$ yaitu $(9,89)$. Hal ini menunjukkan sampel tidak berbeda nyata. Rerata panelis dari hasil uji skoring dan uji hedonik bahwa panelis agak suka terhadap tekstur flakes kelapa dari setiap perlakuan.

\section{Aroma}

Aroma merupakan bau yang khas dari produk yang keluar setelah dilakukan proses pengolahan pada produk tersebut (Darmayanti, 2007). Berdasarkan pengujian uji skoring dan hedonik aroma flakes kelapa yang dilakukan oleh panelis menunjukkan bahwa F-hitung sampel yaitu $(0,07379)$ lebih rendahdari F-tabel pada taraf $5 \%$ yaitu $(4,65)$ dan pada taraf $1 \%$ yaitu $(9,89)$. Hal ini menunjukkan sampel tidak berbeda nyata.

Hasil uji hedonik penelis menunjukkan F-hitung sampel yaitu $(0,0386)$ lebih rendah dari F-tabel pada taraf 5\% yaitu $(4,65)$ dan pada taraf $1 \%$ yaitu $(9,89)$. Hal ini menunjukkan sampel tidak berbeda nyata. Rerata panelis dari hasil uji skoring dan uji hedonik bahwa panelis agak suka terhadap aroma flakes kelapa dari setiap perlakuan.

\section{Warna}

Warna merupakan kenampakan visual yang dapat diamati dengan indra penglihatan terhadap produk. Warna dapat menjadiBerdasarkan pengujian uji skoring dan hedonik warna flakes kelapa yang dilakukan oleh panelis menunjukkan bahwa F-hitung sampel yaitu $(-0,226)$ lebih rendah dari F-tabel pada taraf $5 \%$ yaitu $(4,65)$ dan pada taraf $1 \%$ yaitu $(9,89)$. Hal ini menunjukkan sampel tidak berbeda nyata.

Hasil uji hedonik penelis menunjukkan F-hitung sampel yaitu $(0,0347)$ lebih rendah dari F-tabel pada taraf $5 \%$ yaitu $(4,65)$ dan pada taraf $1 \%$ yaitu $(9,89)$. Hal ini me-nunjukkan sampel tidak berbeda nyata. Rerata panelis dari hasil uji skoring dan uji hedonik bahwa panelis agak suka terhadap warna flakes kelapa dari setiap perlakuan..

Tabel 2. Hasil analisa uji skoring flakes kelapa

\begin{tabular}{ccccc}
\hline Sampel & Warna & Aroma & Tekstur & Rasa \\
\hline TG (100:0) & 1,6 & 1 & 1 & 1 \\
TK (100:0) & 3,2 & 5 & 4,6 & 4,6 \\
TG11 (70:30) & 5 & 3 & 2,8 & 2,8 \\
TG12 (70:40) & 3,8 & 3,8 & 2,8 & 2,8 \\
TG13 (70:50) & 4,4 & 4 & 3,4 & 3,4 \\
TG21 (60:30) & 3,4 & 2,8 & 2,8 & 2,8 \\
TG22 (60:40) & 3,2 & 3,8 & 3,6 & 3,6 \\
TG23 (60:50) & 2 & 3,8 & 3,6 & 3,6 \\
TG31 (50:30) & 3,2 & 3,2 & 3,6 & 3,6 \\
TG32 (50:40) & 3 & 4 & 4 & 4 \\
TG33 (50:50) & 3,4 & 4,4 & 4 & 4 \\
\hline
\end{tabular}




\section{Rasa}

Rasa merupakan sensasi yang didapat ketika mencicipi suatu produk. Sensasi terbentuk oleh adanya perpaduan bahanbahan yang digunakan dalam proses pembuatannya. Suatu produk sangat ditentukan oleh rasa produk (Suarni, 2009). Berdasarkan pengujian uji skoring dan hedonik rasa flakes kelapa yang dilakukan oleh panelis menunjukkan bahwa F-hitung sampel yaitu $(0,0617)$ lebih rendah dari Ftabel pada taraf $5 \%$ yaitu $(4,65)$ dan pada taraf $1 \%$ yaitu $(9,89)$. Hal ini menunjukkan sampel tidak berbeda nyata.

Hasil uji hedonik penelis menunjukkan F-hitung sampel yaitu $(0,0774)$ lebih rendah dari F-tabel pada taraf $5 \%$ yaitu $(4,65)$ dan pada taraf $1 \%$ yaitu $(9,89)$. Hal ini menunjukkan sampel tidak berbeda nyata. Rerata panelis dari hasil uji skoring dan uji hedonik bahwa panelis agak suka terhadap rasa flakes kelapa dari setiap perlakuan.

\section{KESIMPULAN}

1. Perbandingan tepung gandum dan tepung kelapa dalam pembuatan flakes yaitu (70\%: 30\%), (70\%: 40\%), (70\%:50\%), $(60 \%: 30 \%),(60 \%: 40 \%),(60 \%: 50 \%)$, $(50 \%: 30 \%),(50 \%: 40 \%)$ dan $(50 \%$ : $50 \%$ ), sedangkan perbandingan tepung gandum dan tepung kelapa yang tepat dan menghasilkan mutu flakes yang baik yaitu perbandingan (70:30\%).

2. Karakteristik kimia flakes yang dihasilkan yaitu kadar air $(2,237 \%$ $2,587 \%)$, kadar abu $(0,791 \%-0,999 \%)$, kadar lemak $(16,360 \%$ - 20,109\%), kadar karbohidrat $(70,455 \%-76,672 \%)$, kadar serat kasar $(0,299 \%$ - 0,499\%) dan kadar protein $(3,905 \%$ - 5,854\%). Flakes kelapa yang dihasilkan telah memenuhi standar (SNI 01-4270-1996).

3. Berdasarkan hasil uji skoring dan uji hedonik flakes kelapa bahwapanelis menyukai (dapat diterima) flakes kelapa dengan perbandingan 70\%:30\% (tepung gandum : tepung kelapa), berwarna kuning kecoklatan, tekstur renyah dan aroma kelapa.

\section{UCAPAN TERIMA KASIH}

Penulis mengucapkan terima kasih kepada Ibu Dr. Narsih, S.TP. MP, selaku dosen pembimbing PKM-Penelitian dan selaku dosen Jurusan Teknologi Pertanian yang telah membantu dan membimbing PKM ini sehingga bisa menyelesaikan tugas dan tanggungjawab PKM.

\section{DAFTAR PUSTAKA}

Anang. M. dan Nurwantoro,. (2004). Analisa Pangan. Program Studi Teknologi Hasil Ternak Fakultas Peternakan Universitas Diponegoro, Semarang.

Budianto, A.K. (2009). Dasar-Dasar Ilmu Gizi. Pernerbit UMM Press, Malang.

Darmayanti, E., dan Listyorini, D.I. (2007). Pemanfaatan Bekatul Rendah Lemak Pada Pembuatan Kripik Simulasi. Jurnal Gizi dan Pangan, Jakarta.

Monika, Pricilia. (2013). Aktivitas Antioksidan Beras Organik Varietas Lokal 9putih Varietas Cianjur, Merah Varietas Saodah, Hitam Varietas Jawa). Seminar Nasional: Menggagas Ke-bangkitan Komoditas Unggulan Lokal Pertanian Dan Kelautan Fakultas Pertanian Trunojoyo: Madura.

Saputra, H. P., Basito, E. Nurhartadi. (2015). Pengaruh penggunaan tepung koro benguk (Macuna Pruriens) dan tepung mocaf (Modified Cassava Flour) sebagai substitusi tepung terigu ter-hadap karakteristik fisik, kimia dan sensoris cookies. Jurnal Teknosains Pangan.

Suarni. (2009). Produk Makanan Ringan (Flakes) Berbasis Jagung Dan Kacang Hijau Sebagai Sumber Protein Untuk Perbaikan Gizi Anak Usia Tumbuh. Balai Penelitian Tanaman Seralia. 
Sudarmadji, S., Haryono, B., dan Suhardi. (2002). Analisa Bahan Makanan dan Pertanian. Liberty-PAU Pangan dan Gizi UGM, Yogyakarta.

Toha, A. (2001). Biokimia Metabolisme Biomolekul. Alfabeta, Manokwari.

Trinidad, T.P. (2002). Dietary Fiber From Coconut Flour From "Sapal", A Promising Functional Food, Food And Nutrition Research Institute, Department Of Science And Technology, Manila.

Winarno, F. G. (1997). Kimia Pangan dan Gizi. PT. Gramedia Pustaka Utama, Jakarta.

Winarno, F. G. (2002). Kimia Pangan dan Gizi. PT. Gramedia Pustaka Utama, Jakarta. 